HORTSCIENCE 25(11):1388-1391. 1990.

\title{
Nitrogen Leaching from Cypress Wood Chips
}

\author{
Edward F. Gilman', Thomas H. Yeager ${ }^{2}$, and Diane Weigle ${ }^{3}$ \\ Environmental Horticulture Department, Institute of Food and \\ Agricultural Sciences, University of Florida, Gainesville, FL 32611 \\ Additional index words. landscape mulch, PVC columns, nitrogen carriers, nitrogen \\ rate, irrigation rate, Taxodium distichum
}

\begin{abstract}
Columns $(4 \times 15 \mathrm{~cm})$ of incubated $(25 \mathrm{C}, 7 \%$ volumetric moisture $)$ milled cypress [Taxodium distichum (L.) L. Rich] wood chips received $180 \mathrm{mg}$ of each ionic form of $\mathrm{N}$ applied to the surface from dry $\mathrm{NH}_{4} \mathrm{NO}_{3}, \mathrm{KNO}_{3}$, or $\left(\mathrm{NH}_{4}\right)_{2} \mathrm{SO}_{4}$ and were leached daily with $16 \mathrm{ml}$ deionized water (pH 5.5). After 10 days, $>85 \%$ of applied $\mathrm{N}$ leached from the columns in all treatments. After 25 days, all $\mathrm{N}$ leached from the $\mathrm{NH}_{4} \mathrm{NO}_{3}$ and $\mathrm{KNO}_{3}$ treatments, and $93 \%$ leached from the $\left(\mathrm{NH}_{4}\right)_{2} \mathrm{SO}_{4}$ treatment. In subsequent experiments, columns received $360 \mathrm{mg} \mathrm{N}$ from $\mathrm{NH}_{4} \mathrm{NO}_{3}$ and were leached daily with either $16,32,48$, or $64 \mathrm{ml}$ of deionized water for 50 days. The rate of $\mathrm{N}$ leaching increased with increasing water application rate, although total $\mathrm{N}$ leached per column was similar for all water rates after 25 days. Columns that received 45, 90, 180 , or $360 \mathrm{mg}$ N/column were leached daily with $16 \mathrm{ml}$ of deionized water. Nitrogen concentrations in the leachate ranged from $3406 \mathrm{ppm} \mathrm{NO}--\mathrm{N}$ and $2965 \mathrm{ppmNH}_{4}^{-} \mathrm{N}$ at day 5 for the 360-mg rate to 3 and $5 \mathrm{ppm}$, respectively, at day 35 for the $45-\mathrm{mg}$ rate. In all experiments with $\mathrm{NH}_{4} \mathrm{NO}_{3}$, morO $\mathrm{O}_{3}^{-}-\mathrm{N}$ leached than $\mathrm{NH}_{4}^{+}-\mathrm{N}$ and more $\mathrm{NO}_{3}^{-}-\mathrm{N}$ leached than applied, indicating vitrification occurred. $\mathrm{NH}_{4}^{+}-\mathrm{N}$ and $\mathrm{NO}_{3}^{-}-\mathrm{N}$ broadcast over cypress wood chips in the landscape would leach quickly into the soil.
\end{abstract}

Cypress wood chips and bark of various pine (Pinus L.) species are often used as a mulch for landscape plantings in southeastern and subtropical regions of the United States. Such mulches buffer soil temperatures (Ashworth and Harrison, 1983), reduce weed growth, may immobilize soil N, and maintain soil moisture levels (Robinson, 1988). Cypress-mulched landscape plants are commonly fertilized by broadcasting over the

Received for publication 6 Nov. 1989. Florida Agricultural Experiment Station Journal Series no. R-00189. The cost of publishing this paper was defrayed in part by the payment of page charges. Under postal regulations, this paper therefore must be hereby marked advertisement solely to indicate this fact.

${ }^{1}$ Assistant Professor.

${ }^{2}$ Associate Professor.

${ }^{3}$ Lab Technician III surface of the mulch. However, the influence of the cypress mulch on leaching of $\mathrm{N}$ is unknown. Previous research revealed that $\mathrm{NO}_{3}^{-}-\mathrm{N}$ leached rapidly when surface-applied to pine bark, whereas $\mathrm{NH}_{4}^{+}-\mathrm{N}$ leached only after exchange sites were saturated (Foster et al., 1983). We, therefore, determined the influence of $\mathrm{N}$ carriers, $\mathrm{N}$ application rate, and water application rate on $\mathrm{N}$ retention by cypress wood chips.

General procedures. Freshly milled cypress wood chips (whole-ground tree) were passed through a $6.3-\mathrm{mm}$ sieve and ovendried at $60 \mathrm{C}$ to a constant weight. Particle size distribution (by weight, but separated by dimension) was $33.3 \%$ less than $0.5 \mathrm{~mm}$, $46.9 \%$ between 0.5 and $1.4 \mathrm{~mm}, 18.4 \%$ between 1.4 and $4.0 \mathrm{~mm}$, and $1.4 \%$ greater than $4.0 \mathrm{~mm}$ (U.S. Series sieve no. 35, 14, 5 , and 3 , respectively). Total cation exchange capacity of the wood chips was 0.43 

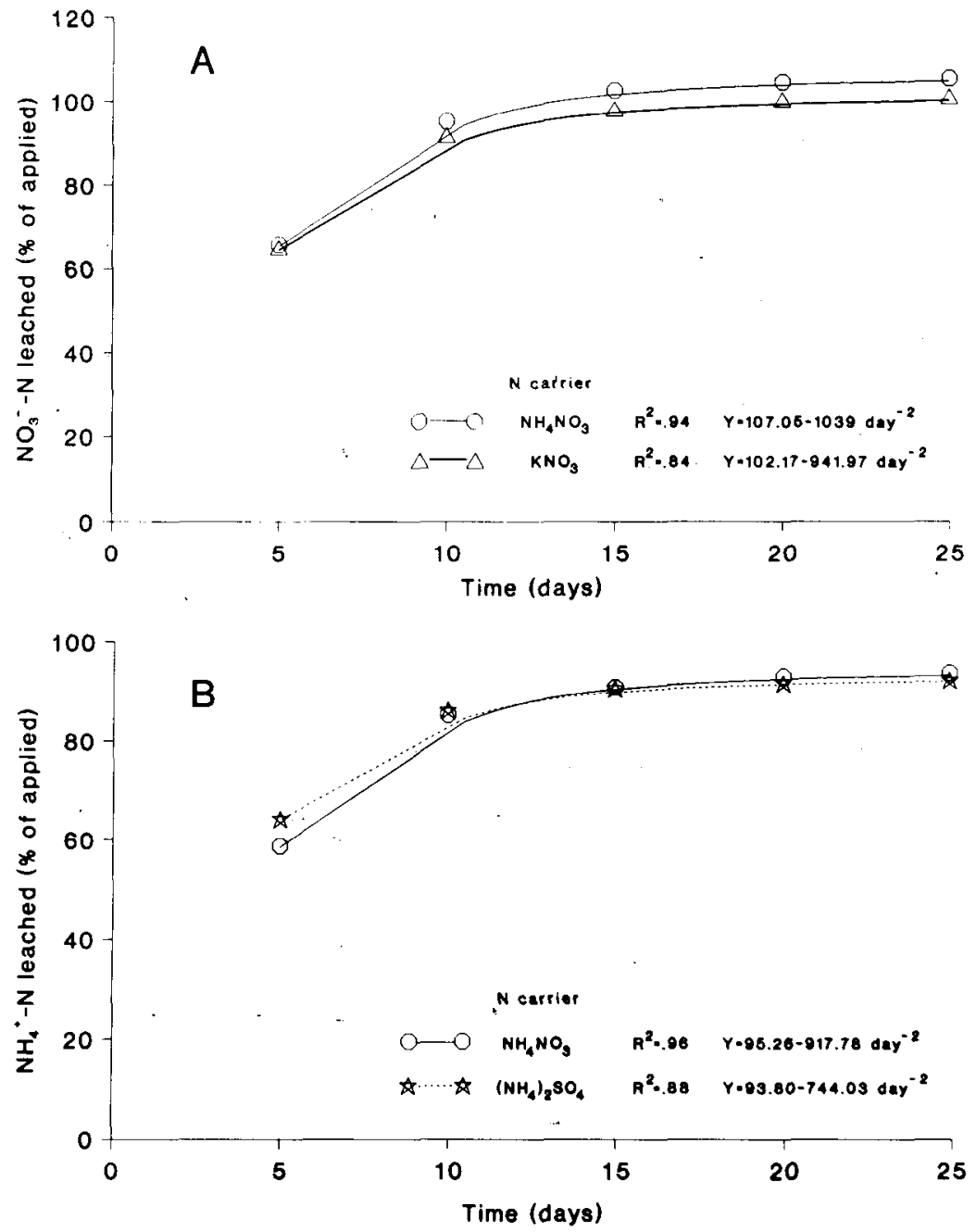

Fig. 1. Percent of applied (A) $\mathrm{NO}_{3}^{-}-\mathrm{N}$ and (B) $\mathrm{NH}_{4}^{+}-\mathrm{N}$ leached from columns of milled cypress wo chips receiving $\mathrm{NH}_{4} \mathrm{NO}_{3}, \mathrm{KNO}_{3},\left(\mathrm{NH}_{4}\right)_{2} \mathrm{SO}_{4}$, or no $\mathrm{N}$ (control). Columns were leached daily w $16 \mathrm{ml}$ of deionized water $\left(\mathrm{pH} 5.5\right.$ ). Less than $0.5 \mathrm{mg} \mathrm{NO}-\mathrm{N}$ or $\mathrm{NH}_{4}^{+}-\mathrm{N}$ leached from the cont (data not presented).

Table 1. Nitrogen applied and leached after 25 days from columns of cypress wood chips that received a dry surface application of one of three $\mathrm{N}$ carriers.

\begin{tabular}{|c|c|c|c|c|}
\hline \multirow{3}{*}{$\begin{array}{l}\text { Nitrogen } \\
\text { carrier }\end{array}$} & \multicolumn{4}{|c|}{ Nitrogen (mg N/column) ${ }^{z}$} \\
\hline & \multicolumn{2}{|c|}{$\mathrm{NH}_{4}^{+}-\mathrm{N}$} & \multicolumn{2}{|c|}{$\mathrm{NO}_{3}^{-}-\mathrm{N}$} \\
\hline & Applied & Leached & Applied & Leached \\
\hline $\begin{array}{l}\text { None } \\
\text { (control) }\end{array}$ & 0 & $\ldots y$ & 0 & -.. \\
\hline $\mathrm{NH}_{4} \mathrm{NO}_{3}$ & $180^{y}$ & $171^{* *}$ & 180 & $191^{* *}$ \\
\hline $\mathrm{KNO}_{3}$ & 0 & --- & 180 & $183^{\text {NS }}$ \\
\hline$\left(\mathrm{NH}_{4}\right)_{2} \mathrm{SO}_{4}$ & 180 & $168^{* *}$ & 0 & $\cdots$ \\
\hline
\end{tabular}

${ }^{2}$ Mean of 10 columns; columns were leached with $48 \mathrm{ml} \cdot$ day $^{-1}$ on day 1 and $16 \mathrm{ml} \cdot$ day $^{-1}$ thereafter for 25 days.

${ }^{y}$ Less than $0.5 \mathrm{mg} \mathrm{N}$.

**,NSSignificantly different from amount applied at $P=0.01$ or nonsignificant, respectively.

meq/100 $\mathrm{cm}^{3}$ and anion exchange capacity was $0.013 \mathrm{meq} / 100 \mathrm{~cm}^{3}$ (Agro Services International, Orange City, Fla.). Plastic bags containing $28 \mathrm{~g}$ of cypress wood chips were hand shaken for $1 \mathrm{~min}$ after addition of 11.2 $\mathrm{g}$ of deionized water and incubated at $25 \mathrm{C}$ in a Precision Incubator Model 818 (SGA/ Precision Scientific Group, Chicago). frozen untiNO ${ }_{3}^{-}-\mathrm{N}$ and $\mathrm{NH}_{4}^{+}-\mathrm{Nwere}$ determined with an Orion Ionalyzer Model 901 using the Model 93-07 $\mathrm{NO}_{3}^{-}$electrode and the Model 93-12 NH electrode (Orion Research, Boston).

Nitrogen carriers (Expt. 1). After 35 days of incubation, cypress wood chips were placed in columns and $360 \mathrm{mg} \mathrm{N} /$ column from $\mathrm{NH}_{4} \mathrm{NO}_{3}$ or $180 \mathrm{mg} \mathrm{N} /$ column from $\mathrm{KNO}_{3}$ or $\left(\mathrm{NH}_{4}\right)_{2} \mathrm{SO}_{4}$ was evenly distributed on the cypress surface. Ten columns $(4 \times 15 \mathrm{~cm})$ received each $\mathrm{N}$ carrier and 10 did not. Each column was leached the first day with $48 \mathrm{ml}$ of deionized water to thoroughly wet the cypress wood chips. Thereafter, each column received $16 \mathrm{ml}$ daily until termination of the experiment on day 25 . Leachates from five consecutive days were combined into one sample for $\mathrm{NO}_{3}^{-}-\mathrm{N}$ and $\mathrm{NH}_{4}^{+}-\mathrm{N}$ determination.

Water rate (Expt. 2). After 48 days of incubation, cypress wood chips from each plastic bag were placed in a PVC column (4 $\times 20 \mathrm{~cm}$ ). To eliminate indigenous $\mathrm{N}$ from the wood chips, each column was leached with $48 \mathrm{ml}$ of deionized water daily until the leachate $\mathrm{NO}_{3}^{-}-\mathrm{N}$ concentration was $<1 \mathrm{ppm}$ (14 days). Then, $360 \mathrm{mg} \mathrm{N} /$ column from $\mathrm{NH}_{4} \mathrm{NO}_{3}$ was evenly distributed on the surface of the cypress wood chips. Deionized water was applied to each of 10 columns at $16,32,48$, or $64 \mathrm{ml} /$ column daily until day 50. Leachate from each column was collected separately for days 1 through 15 and then every 5 th day to day 50 . Leachates were combined from days 16 to 19 and 21 to 24 .

Nitrogen rate (Expt. 3). After 35 days of incubation, eight columns received $\mathrm{NH}_{4} \mathrm{NO}_{3}$ at either $0.0,45,90,180$, or $360 \mathrm{mg} \mathrm{N} /$ column. Each column was leached the first day with $48 \mathrm{ml}$ of deionized water to thoroughly wet the cypress wood chips. Thereafter, each column received $16 \mathrm{ml}$ deionized water daily for 50 days. Leachates were collected every 5 th day until day 50 .

Sixty-five percent of applied $\mathrm{NO}_{3}^{-}-\mathrm{N}$ and $\approx 60 \%$ of $\mathrm{NH}_{4}^{+}-\mathrm{N}$ leached from the cypress wood chips by day 5 in Expt. 1 (Fig. 1 A and B). Ninety-two percent and $85 \%$ of applied $\mathrm{NO}_{3}^{-}-\mathrm{N}$ and $\mathrm{NH}_{4}^{+}-\mathrm{N}$, respectively, leached by day 10 , a result similar to that with pine bark in which $>95 \%$ of the $\mathrm{N}$ from $\mathrm{NH}_{4} \mathrm{NO}_{3}$ leached after 8 days (Foster et al., 1983).

Total $\mathrm{NH}_{4}^{+}-\mathrm{N}$ leached from $\mathrm{NH}_{4} \mathrm{NO}_{3}$ and $\left(\mathrm{NH}_{4}\right)_{2} \mathrm{SO}_{4}$ was less than that applied, indicating sorption by the wood chips and/or volatilization (Table 1). Nitrification may also have occurred and resulted in more $\mathrm{NO}_{3}^{-}-\mathrm{N}$ leached than was applied. However, negligible $\mathrm{NO}_{3}^{-}-\mathrm{N}$ was recovered for the $\left(\mathrm{NH}_{4}\right)_{2} \mathrm{SO}_{4}$ treatment, and leachate $\mathrm{pH}$ was similar for all carriers (6.2). Nitrate $\mathrm{N}$ leached from $\mathrm{KNO}_{3}$ was similar to that applied.

Nitrogen leached at a faster rate as water application rate increased (Fig. $2 \mathrm{~A}$ and B). However, more water was required to leach a given amount of $\mathrm{N}$ at the higher water rates than at the lower rates. For example, a total of $256 \mathrm{ml}$ of water applied over 4 days at 64 ml-day ${ }^{-1}$ leached $86 \%$ of the $\mathrm{NO}_{3}^{-}-\mathrm{N}$, whereas only $176 \mathrm{ml}$ was required to leach this amount 

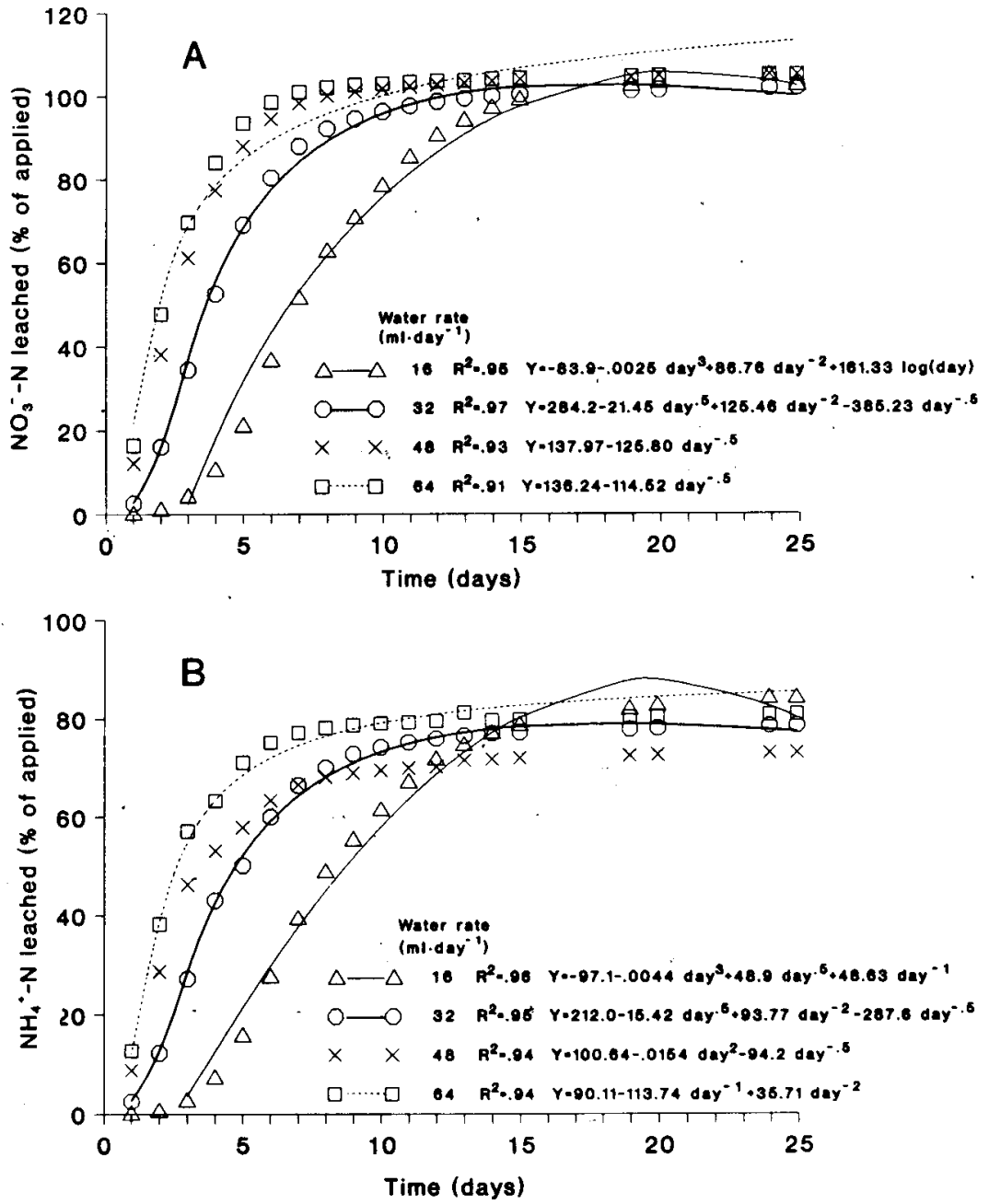

Fig. 2. Percent of applied (A) $\mathrm{NO}_{3}^{-}-\mathrm{N}$ and (B) $\mathrm{NH}_{4}^{+}-\mathrm{N}$ leached from columns of milled cypress wood chips receiving $16,32,48$, or $64 \mathrm{ml}$ of deionized water (pH 5.5) daily. Each column received a surface application of $360 \mathrm{mg} \mathrm{N}$ from $\mathrm{NH}_{4} \mathrm{NO}_{3}$.
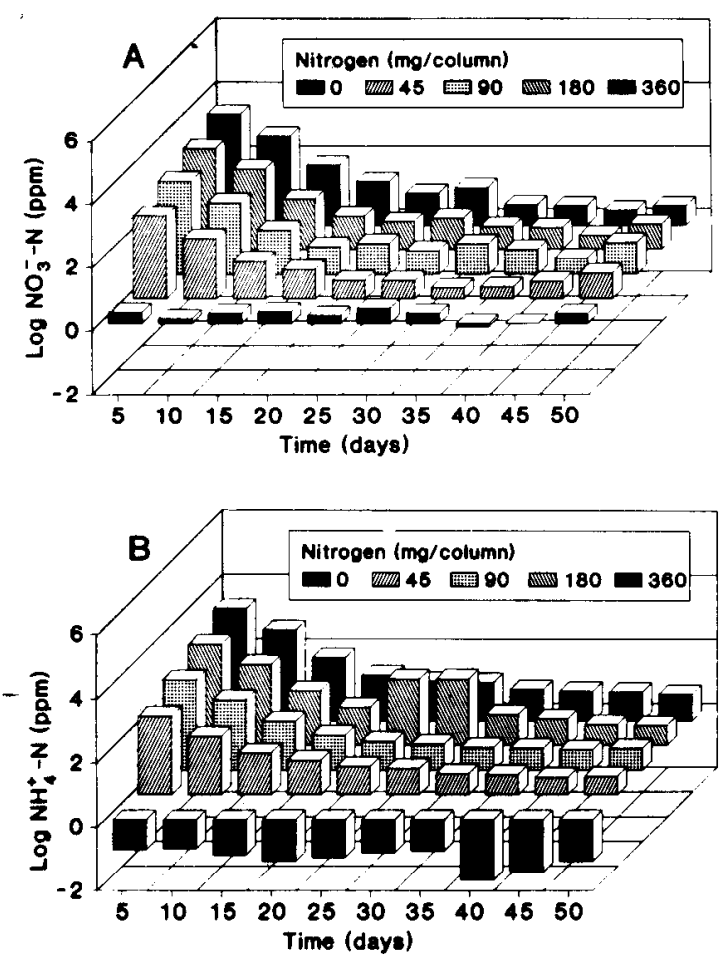

Fig. 3. $\log _{10}$ of (A) $\mathrm{NO}_{3}^{-} \mathrm{N}$ and (B) $\mathrm{NH}_{4}^{+}-\mathrm{N}$ concentrations of leachate from columns of milled cypress wood chips receiving $0,45,90,180$, or $360 \mathrm{mg} \mathrm{N}$ from $\mathrm{NH}_{4} \mathrm{NO}_{3}$. Each column was leached daily with $16 \mathrm{ml}$ of deionized water $(\mathrm{pH} 5.5)$. 1390 at the 16-ml-day ${ }^{-1}$ rate. This result indicates that a single rainfall event of $5 \mathrm{~cm}$ would leach less $\mathrm{N}$ than two events of $2.5 \mathrm{~cm}$. Regardless of water rate, more $\quad \mathrm{NO}_{3}^{-}-\mathrm{N}$ leached than was applied, indicating that nitrification occurred.

The $\mathrm{NO}_{3}^{-}-\mathrm{N}$ and $\mathrm{NH}_{4}^{+}-\mathrm{N}$ concentrations during Expt. 2 decreased rapidly for each water rate and were lowest at the higher water application rates due to the dilution effect of the greater water volume (data not presented). Total $\mathrm{N}\left(\mathrm{NO}_{3}^{-}-\mathrm{N}\right.$ plus $\left.\mathrm{NH}_{4}^{+}-\mathrm{N}\right)$ concentration for the $16-\mathrm{ml} \cdot$ day $^{-1}$ treatment on day 25 was $<80 \mathrm{ppm}$, an optimal level for container-grown 'Helleri' holly (Ilex crenata Thunb.) (Niemiera and Wright, 1982; Wright and Niemiera, 1985). Total $\mathrm{N}$ concentration in Expt. 3 for the 360-mg rate was < 80 ppm by day 20 (Fig. $3 \mathrm{~A}$ and B). At the $45-\mathrm{mg}$ rate (equivalent to $140 \mathrm{~g} \cdot \mathrm{m}^{-2}$ ), total $\mathrm{N}$ concentration in the leachate was $<80 \mathrm{ppm}$ by day 10 , after $15 \mathrm{~cm}$ of water was applied. Nitrate-N and $\mathrm{NH}_{4}^{+}-\mathrm{N}$ concentrations on day 50 ranged from 5 to $7 \mathrm{ppm}$ for the $360-\mathrm{mg}$ treatment and from 7 to 4 ppm for the 45 mg treatment, respectively.

More than $92 \%$ of the $\mathrm{NO}_{3}^{-}-\mathrm{N}$ and $85 \%$ of the $\mathrm{NH}_{4}^{+}-\mathrm{N}$ leached through cypress wood chips from a surface application of $\mathrm{NH}_{4} \mathrm{NO}_{3}$, $\mathrm{KNO}_{3}$, or $\left(\mathrm{NH}_{4}\right)_{2} \mathrm{SO}_{4}$ after applying $15 \mathrm{~cm}$ of water over 10 days. Leaching was faster at the higher water application rates. Therefore, $\mathrm{NH}_{4}^{+}-\mathrm{N}$ and $\mathrm{NO}_{3}^{-}-\mathrm{N}$ broadcast over cypress wood chips in the landscape would leach rapidly into the soil. Leaching would be slower from water-insoluble $\mathrm{N}$ carriers that are often used to fertilize landscapes. Concentration of $\mathrm{N}$ leaching from cypress wood chips that received $45 \mathrm{mg} \mathrm{N}\left(140 \mathrm{~g} \cdot \mathrm{m}^{-2}\right)$ was $>80$ ppm only for the first 10 days after fertilizer application when $12 \mathrm{~mm}$ of irrigation water was applied daily. Since, for most of the year, many landscapes do not receive water at this rapid rate, application of soluble $\mathrm{N}$ fertilizer would result in leachate concentrations $>80 \mathrm{ppm}$ for longer than 10 days. Although optimum growth for woody plants in containers occurs at $80 \mathrm{ppm} \mathrm{N}$, the optimum concentration for plants growing in the landscape is not known.

The amount of $\mathrm{N}$ leached through cypress wood chips can be reliably predicted as a function of time at a constant water application rate. This function is fairly consistent among a variety of soluble $\mathrm{N}$ carriers. The rapid leaching of soluble $\mathrm{N}$ emphasizes the need for fertilizing landscapes with controlled-release $\mathrm{N}$ carriers. Leaching characteristics of controlled-release $\mathrm{N}$ carriers and those of soluble carriers remain to be compared.

\section{Literature Cited}

Ashworth, S. and H. Harrison. 1983. Evaluation of mulches for their use in the home garden. HortScience 18:180-182.

Foster, W.J., R.D. Wright, M.M. Alley, and T.H. Yeager. 1983. Ammonium adsorption on a pinebark medium. J. Amer. Soc. Hort. Sci. 108:548551.

Niemiera, A.X. and R.D. Wright. 1982. Growth of Ilex crenata Thunb. 'Helleri' at different substrate nitrogen levels. HortScience 17:354-355. Robinson, D.W. 1988. Mulches and herbicides in HortSCIENCE, Vol. 25(11), November 1990 
ornamental plantings. HortScience 23:547-552.

Wright, R.D. and A.X. Niemiera. 1985. Influence of $\mathrm{N}, \mathrm{P}$ and $\mathrm{K}$ fertilization interactions on growth of Ilex crenata Thunb. 'Helleri'. J. Environ. Hort. 3:8-10.

Yeager, T.H. and J.E. Barrett. 1984. Phospho- rous leaching from ${ }^{32} \mathrm{P}$-superphosphate-amended soilless container media. HortScience 19:216217. 